\title{
Configuration of value system on rural entrepreneurs at Tasikmalaya West Java Indonesia
}

\author{
Hidayat, Dede Rahmat $\triangle$ \\ Universitas Negeri Jakarta, Indonesia(d_r_hidayat@yahoo.com)
}

Received: 8 August 2014 Available Online: 10 January 2015
Revised: 28 December 2014 DOI: $10.5861 /$ ijrsp.2015.994

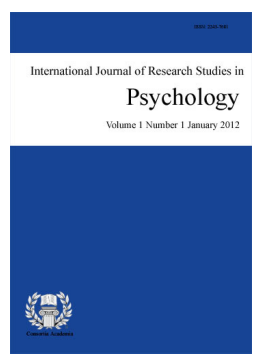

Accepted: 4 January 2015 Online ISSN: 2243-769X

OPEN ACCESS

\section{Abstract}

The aim of study was to examine the form of the configuration of the value system on entrepreneurs who are owner of small and medium enterprises at Tasikmalaya, West Java. The kind of research is survey, amount of respondents are 413 persons who has chosen by purposive sampling technique, they are producers of traditional industry at Tasikmalaya, such as handicraft, embroidery, and sandals. An instrument which has used to measure value is the value systems from Spranger which are 6 values contains, there are theory (science), economic, religiosity, social, power and art (aesthetic). Result of the study was found that religiosity and social values as the dominant value of the system, meanwhile economic value as the important value for business only at the third place. In correlation with success as an entrepreneur, result of analysis has found there were non-significant correlation between each value of the value system and success. Indicator of success for the enterprise are number of employee, income, and property ownership, like as vehicle, plant (place of manufacture) and assets. Those are entire system result correlation between value and success. Value of theory is $r=-.019$, Economic value is $r=-.084$, social value is $r=-.017$, value of the power $=-.019$, religiosity value is $r=.002$, value of art (culture) $r=.023$. The conclusion of this research is the configuration of the system of value on rural entrepreneurs at Tasikmalaya is dominated by social and religiosity value. In this perspective of modern business is not supporting to developing their business but for themselves business are not only about to increase of income earnings but the way to helping to others.

Keywords: value systems; rural entrepreneurs; small and medium enterprises 


\section{Configuration of value system on rural entrepreneurs at Tasikmalaya West Java Indonesia}

\section{Introduction}

Entrepreneurship is the important part of economic development and a country; there were providing work opportunity and offering goods and services (Baum \& Locke 2004). Entrepreneurship also were stimulating and supporting economic activity to improve national's competitiveness (Zahra, 1999), so it's make entrepreneur as the primary agent of change and prosperity.

In general the majority of entrepreneurs are mostly micro and small entrepreneur. They have important rules to national economic growth. Similar situation also occurred at Indonesia, mostly industries are micro and small industries, and it's located at rural (Raharjana, 2005). The existence of small industry at rural has a savior for the economic life of the local's pupil. Small industry is providing job opportunities, especially when agriculture sector has declined. According Saleh (in Raharjana, 2003), the beneficiary of the small industry at rural are: a) the costs of expense are smaller due to the raw materials are from natural's environment (surround); b) the price of the product are cheaper appropriate for lower income class; and c) Demanding that products are always available. Moha Asri (1997) was adding the beneficiary of small industry are a) fostering to improving income earnings for nations due to financing and capital sources are from their own; b) Improving the gain of the income for the community; c) being of the training place for the employee and entrepreneur; and also d) establishing the foundation of the national's industry. Hence small industries have more functions, those to be media for transfer of technology's perspective, improving the quality of goods etc. Overwhelming, the beneficiary for the nation is not only economic but social and politic aspect (Sadoko, 2004).

Study of Indonesian's entrepreneurs especially for the rural entrepreneur is almost related with socio-culture factors. Which has influencing to behavior of communities, especially from rural entrepreneurs who hold traditional close's culture? Socio-culture giving direction for behavior because to be a role model for the individual's value system.

\section{Conceptual}

The part of culture factor has giving direction to behave is value system. Value has special position and the ultimate component in culture. By value we can differentiate culture on each other's (Sutan Alisjahbana, 1977), include the culture of family, gender and job (Hofstede, 1980). The value is "a standard or criterion to choose the orientation of various alternatives" (Kao \&Hong, 1988). Values was studied, internalized, integrated and organized by individuals and will before a value system. Rokeach (1973) said value system will be part structure of psychology of men. Value determined by standard for all people. Spranger (in Sumadi Suryabrata, 1983) and Sutan Alisjahbana (1977) forming the value system configuration for everyone. Those are containing six values: theory (science) value, economic value, religiosity value, aesthetic (art) value, power (politics) value and social value. All of values explaining how to behave can be found in future readings (such as Kroeber, 1948, Sutan Alisjahbana, 1977, and Mustaffa Omar, 2002, 2008).

According Sutan Alisjahbana (1977), Indonesians values are culture dominated by religiosity value, and then social and aesthetic. Knowledge value are very weak due to rational thinking are not developed yet. The economic value is also not developed yet too because natural resources has providing many necessities for life, and this is make assumption that hard work is not needed. Lack of objective and logical thinking make someone not incite to work hard. In this relation, authorization and power are from supernatural power, so successfully not determine by hard work, this believe make anyone eager to hard work to achieve his glory (Redding, 1980, Ravrisond Baswir, 2000). 
Based on the explanation of Alisjahbana about progressive values, Koentjoroningrat (1983) states that employers supported by progressive values will be able to prevail in the industry; progressive values are driving to the prosperity. The high economic value would encourage the growth productivity (Kartodirdjo 1994). Diaz and Rodriguez (2003) conducted a study on the value system upon entrepreneurs which an member of cooperation at Andalusia (Spain), has found if values that held in high ratings by entrepreneurs are the value of welfare and justice (health, a world peace, responsibility and honest), then the value of competitive (enthusiasm life and aspiring) then the value of the arts and sciences.

The value of science has purpose to find out about natural objective, recognize objects or events that we face. The economic value is also aiming to use objects and events base on logical efficiency to achieve the benefit of the pleasures of life. In terms of culture, the combination value between theory (science) and economic are referred as progressive aspect. Religious and holiness values are appraisal process about environment which has secret of the greatness of universe. Aesthetic value form if tasted beauty. The combination of religious and aesthetic value is called the expressive aspects of culture. Integrative value is valuing process for fellow human beings in relations of power and solidarity. In the valuing process the target power is power, it we will be felt if someone else is to follow the norms and values that we determined. Social values closely related to the relationship of love, friendship, sympathy for fellow human beings, and respect for others as individuals or unique groups.

\section{Table 1}

Summary of valuing process and values

\begin{tabular}{lll}
\hline \multicolumn{1}{c}{ Aspect } & \multicolumn{1}{c}{ Value } & \multicolumn{1}{c}{ Orientation } \\
\hline Progressive & Theory & $\begin{array}{l}\text { Knowing about natural surrounding by objective of determining the identity } \\
\text { of objects and events. } \\
\text { Using objects and events with the basic logic of efficiency and useful to } \\
\text { achieve pleasure. }\end{array}$ \\
\hline Expressive & $\begin{array}{l}\text { Religion } \\
\text { Art }\end{array}$ & $\begin{array}{l}\text { An expression of the secret of life and greatness of universe } \\
\text { The beauty that is both expressive on objects and events }\end{array}$ \\
\hline Integrative & $\begin{array}{l}\text { Power } \\
\text { Social }\end{array}$ & $\begin{array}{l}\text { Feeling satisfied if have authorityy and power over others } \\
\text { Love, friendship, sympathy for fellow human beings, and efforts are } \\
\text { appreciated and helpful }\end{array}$ \\
\hline
\end{tabular}

Source: Sutan Alisjahbana, 1977

All of six values determining the form of personality, everyone have a pattern of culture or configuration which is different in uniquely all the layer of society. Based on it, the person will be embodying a distinctive pattern or configuration of the six values and valuing process. The parameter of success in the study of entrepreneur divided into two different indicators. The first, success has indicated by material and should be seen. The second, indicator of success are immaterial and should not be seen (intangible). Following the first indicator, it may be concluded if someone said success as entrepreneur if he/she obtained the increase value of capital, have workers increasingly number and growing personal wealth. Indicators of success from Kit Sum Lam (1999) and Krauss et al. (2005) are among the indicators are widely used in various studies on entrepreneurship success, as there is in the studied by economics, sociology, anthropology and also on psychology. By development perspective, the success would be more easily determined by the achievement of something that should be seen and clear. The latter indicators are subjective and not visible, for example peace, desire to give and preserve the company (Foley, 2003). In this study the first indicator that will be used.

\section{Method}

\subsection{Subjects}

The subjects of present study are entrepreneurs who have own micro, small and medium enterprises in Tasikmalaya West Java. They were selected by purposive sampling technique, Subject or respondent has 
Hidayat, D. R.

followed on certain characteristics: Entrepreneurs who have their own businesses, not workers, staying in Tasikmalaya, Sundanese Ethnic, Religious Muslim, Produce handicraft, such as sandals, embroidery and decoration house, the total amount of sampler are 413 people.

\subsection{Questionnaire}

Data was collected by questionnaire, namely value system questionnaire which has constructed based on theory of Spranger and Sutan Alisjahbana, the component of value are economic value, religiosity value, artistic value, power (political) value and social value. Numbers of entire question are 30 items. Each value has measured in 5 Likert scale, the lowest is 1 and the highest is 5 ( $1=$ never and $5=$ always $)$. Lowest score total is 30 and the highest score total is 150 . The questionnaire has examined for validity and reliability in preliminary study, validity examined by correlation scores-total and reliability by Cronbach's $\alpha$. Validity score begins 0.21 until 0.75, when Cronbach's $\alpha$ score are 0.71 to 0.78 ; while the success was measured by looking at the achievements of commerce (business performance) as done in Krauss et al. (2005). The Success of the economy is measured through achievement of the following: employment, income, property ownership like as amount of house and vehicles, assets. Each measure is given a score of economic achievement, starting from the lowest score is 1 and highest is 3 .

\subsection{Kind of research}

The kind of present study is review analytical. Following Smith and Davis (2004) Study were used for analytical review explaining relationship between variables and so make predictions. Two kinds statistical analysis has used to descripting and explaining correlation between variables, those are descriptive analysis and inference

\section{Results of study}

\subsection{Configuration of values system}

Three values which are get highest are religious values ( $\mathrm{min}$ score $=3.26$ ), followed by social values (min score $=2.92$ ) and economic value $(\min$ score $=2.73)$. Values of power and science have same score $($ score $=2.6$ $\min$ ) and the lowest score is the value of art (min score $=2.27$ ).

Table 2

Descriptive result of configuration of value system

\begin{tabular}{clccccc}
\hline & Value System & Low & Middle $(\%)$ & High & Mean & Scale \\
\hline 1 & Science & $35(8.5)$ & $315(76.3)$ & $63(15.3)$ & 2.6 & $1-5$ \\
2 & Economics & $33(8)$ & $257(62.2)$ & $123(29.8)$ & 2.73 & $1-5$ \\
3 & Power & $10(2.4)$ & $297(71.9)$ & $106(25.7)$ & 2.6 & $1-5$ \\
4 & Social & $33(8)$ & $323(78.2)$ & $57(13.8)$ & 2.92 & $1-5$ \\
5 & Religiosity & $3(0.7)$ & $227(55)$ & $183(44.3)$ & 3.26 & $1-5$ \\
6 & Aesthetic & $90(21.8)$ & $292(70.7)$ & $31(7.5)$ & 2.27 & $1-5$ \\
\multicolumn{5}{l}{ Scores mean: $3.67-5.00$, categorized 'high"; score mean 2.34-3.66 categorized 'middle', score 1.00-2.33 categorized as 'low' }
\end{tabular}

Result of this study has shown small and micro entrepreneurs at Tasikmalaya still have strong religious orientation. Religious activity is very overlooked by them. Religious values have encouraged involving in various religious activities, especially related to the five pillars of Islam. Social value is also higher than other values, due to upholding the values of cooperation and brotherhood by religionists. Brotherhood relationships and rural life style based on fraternal bond becomes binding in civic life. Until now the business activity that has done and modernization process does not lead to social value to be low. They are still keeping the traditional values of life. 
Economic and science value as a progressive value has not been a major value for entrepreneurs at Tasikmalaya. This result has explain why Tasikmalaya's small businesses hard to make progress. They have not applied the principles in the process of efficient spending, less to improve competitive advantage and less concern to capital growth.

\subsection{The correlation between the value systems with success}

Result of inference statistical analysis has shown that it studies does not support the initial hypothesis. Hypothesis which declares there is relationship between the value systems with successfully on entrepreneur has rejected, there is no significant relationship entire of six values (the value of science, economic, power, social, religious and aesthetic) of value system with success. Moreover, those are negative correlation with success. This study has demonstrated that the success of small businessmen is not determined by a value system that is owned by the employer.

Table 3

Matrix correlation between the value systems with success

\begin{tabular}{lcc}
\hline \multicolumn{1}{c}{ Value system } & Success & $\mathrm{p}>0.05$ \\
\hline Science & -.019 & n.s. \\
Economic & -.084 & n.s. \\
Social & -.017 & n.s. \\
Power & -.019 & n.s. \\
Religious & .002 & n.s. \\
Aesthetic & .023 & n.s. \\
\hline Note. *significant correlation at the level of 0.05 (2-tailed) &
\end{tabular}

\section{Discussion}

The result of study has demonstrated that entrepreneurs at Tasikmalaya still have a strong orientation to be religious. Commercial activities are become a way for carrying out God's command for them. Entrepreneurs at Tasikmalaya are a devout follower of Islam and tried to run the commercial in order to fulfill all the pillars of Islam including Hajj. For most Muslims at Tasikmalaya, Hajj is the highest form of perfection in worship, you indulge it only applies to those who have the ability to attempt to get through it. In this study, several entrepreneurs already becoming hajj, the pilgrimage is his deep into one of the signs rather than glory so that it will be a major priority in life.

The result of this study, according with Alexander's study (1999) about businessmen from other area at Indonesia; Alexander found that wealth collected through commercial used by mostly businessmen for his Hajj. Hajj pilgrimage is a very important matter. Also added, work and worship with good adherence to God's will realize. For entrepreneur at Tasikmalaya; existence of high religious value is belief in God will exalt grade for who has contribute their wealth for the common good, and likes to contribute to religious activities, such as zakat, infaq or sodaqoh.

According with Gladney's study (1999) that has studying on Hui Muslim businessmen at China; they avail wealth for them not only for personal gain but for the servicing to society and religion. Furthermore, Gladney (1999) explaining if for Hui businessmen, God is the source of his wealth. For a number of profits that they donate proceeds to develop symbols of Islam through developing of mosques. Furthermore, social values are at the middle to high level, it has shown that the orientation towards high social value is very dominant in the lives of entrepreneurs at Tasikmalaya. They assume if the essential of commercial activity is obtaining to profit, that to be an instrument for social purposes. For among of entrepreneurs, fostering commercial is mean they open up employment opportunities for the relatives and neighbor, so it is more relatives and neighbor can receive benefits of business activities. Highly social value also shown on wages for workers. Determination of the amount of wages to workers is often based on the mercy and not always based on productivity, this result according with 
Foley (2003) who has studied on indigenous Australian Entrepreneurs.

Existence of social value is involvement in education and religious foundation. Mostly among of employers who take charge or be a permanent donator of various foundations. They contribute to the profit of commercial gain for educational and religious activities, including orphans home. Researcher found that there are employers used the profits to build schools for the poor. They fulfill all the needs for learning and liberate all students' tuition. Everything has been done is to give satisfaction and make they feel meaningful life by can help others.

Although, a high social value can deduct gains in trade, but essentially it was a resurfacing of social capital. This is a collective resource that can keep them in order to continue sustainable commerce (Mohammad Sobary, 1995). According to Flora (1998) and Putnam (1973), social capital is seen as an important element in the economic development of society. Social capital in the local community can be used as a key strategy in order to supporting the sustainable development (World Bank, 2001; Ahimsa Putra, 2003).

Pattern of social relations entrepreneur are neighborhood and not make social relations as an instrument for the benefit of commerce. It was different with social values of Chinese entrepreneurs, social relationships pattern for them namely guanxi, it is a social relationship pattern that fostered for the benefit of commerce and become an instrument for the advancement of the business (Mohapatra et al., 2007). In traditional Chinese culture emphasizes the interpersonal relationships that provide benefits to commercial, there similar among Chinese or with non-Chinese people (Mohapatra et al., 2007; Redding, 1980).

Economic value in the form of small entrepreneurs' commerce activity at Tasikmalaya is in utilizing various raw materials that available in nature around to be something valuable goodies. Handicraft is produced from the raw materials that are around, such as lidi (palm leaf rib) bamboo, or pandanus. Entrepreneur processing of these materials into the tools and houses decor. Tasikmalaya's entrepreneurs have economic value at the middle level that is make they are less proactive in making capital investment. They are generally less involved in advancing economic power, are more likely to engage in small-scale economic activities, less productive and output orientation is still in the subsistent stage.

In terms of the science value, Tasikmalaya's entrepreneur have a value of science are middle and tend to be low. By its condition that make they lack to increase knowledge and get information regarding the various new technologies which may promote their business. Science value at middle level also make they lack to increase professionalism and a desire to increase knowledge for expanding production capacity. Although some of entrepreneurs had attended workshops and training motivation (Achievement Motivation Training) is undertake by government, but less of them were not interested. While the value of science which tends to lower its make entrepreneur hard to make progress in business (Raharjana, 2003).

Among of causes the value of science at the middle to lower; because majority of Tasikmalaya entrepreneur have low educational level. Level of education will be differing perspective in view of science and technology. For lower educated using technology not based on logic efficient and aims to improve productivity, but cause indulge during follow trends. Not much Entrepreneurs success with low education, if success they have valuing science and technology, trying to follow the various training and trying to obtained the intimation that relates to progress.

Value of power of entrepreneurs at Tasikmalaya is at the middle level and tends the low. Low value of the power caused of low political interest. Not much entrepreneurs have involved in political party or become a member of business organization which has a political role. Entrepreneurs are more interested to engage in social and religious organization that not has a set role for the interests of employers. Case is among the causes why entrepreneurs lack access to various support of government, such as credit schemes, training for small businesses, as well as the ease of marketing their products.

Referring to the value of art, art appreciation from entrepreneurs at Tasikmalaya showed at the low level. 
Utilizing of art has been translated to the value of the market economy. For entrepreneur art is for art, they just use the art for pleasure and to preserve from extinction. By this way art should not be something that is commercialized, it causes high artistic value does not contribute to its former success, especially indicator of success is something that is immaterial and assessed from the amount of income, instead of the way people appreciate and be proud of the art heritage of previous generations.

\section{Conclusion}

Configuration of values system of entrepreneur at Tasikmalaya not occupies characteristics of the cultural industry such as Sutan Takdir Alisjahbana (1977). In industrial societies, the dominant value is the science and economic value. Low value of science due to rational thinking is not developed yet, the economic value has not been developed yet too because natural resources not to encourage them to strive harder and more innovative. Correlation analysis demonstrated that the value system is not related with success. Instead of the entire of value that has no significant correlation with success. In the regression analysis also found if value system does not contribute to success.

This result is also demonstrated that the traditional view more concerned to common interest not much change in the past of Sundanese people as dominant people at Tasikmalaya (Yus Rusyana in Anton Athoillah Hashim et al., 2003). Sundanese culture (as dominant culture at Tasikmalaya) for Tasikmalaya society is still dominated by the social and religious orientation. The behavior of "compassion reciprocal (silih asih), grindstones reciprocal (silih asah), and foster reciprocal (silih asuh) (Edi, 2005; Elis Suryani, 2007), in the form of helping neighbor and relatives. They will not hesitate to help others facing hardships. In some cases, found entrepreneur who use the capital to help a sick neighbor, so that the capital expenditure to be reduced is not enough material to be issued.

Some entrepreneurs are having succeeded if they were able to run the pillars of Islam perfectly and can provide more giving (shodaqoh) and charity. For small entrepreneur at Tasikmalaya a pilgrimage to Mecca is a form of glory, when the commercial activities undertaken to give him financial capital for pilgrimage and pay Zakat then they meaningful enough to prevail. Everything are concerning to the belief that the relationship between the human person in order to get along the desired norms and rules issued by the religion. It may be concluded if entrepreneurs at Tasikmalaya actually who succeed, but with differing indicators.

The implications of practice, this research related to the development of entrepreneurship in society. The government has to pay attention to aspects of the values and beliefs of entrepreneur in managing the company, because it will affect the success. In the case of Tasikmalaya's entrepreneurs, they allow being able to set up a company, but generally less able to grow and thrive even stagnated. For it is necessary assistance to enable them to develop their business to be wider, for example by training entrepreneurs to be more professional in business management. This assistance will not eliminate the belief; even contrary by the business professionally managed they can help family and neighbor a broader and more to contribute to the social and religious activities.

\section{References}

Ahimsa-Putra, H. S. (2003). Economic, moral, political rational in small industries in Java: The essays of economic anthropology [in Bahasa Indonesia]. Yogyakarta: Kepel.

Alexander, J. (1999). Women entrepreneurs in the markets of Java: ethnicity, gender and entrepreneur spirit [in Bahasa Indonesia]. In R. W. Hefner (Ed.), Market cultures: Society and morality in the new Asian capitalism (pp. 24-84). Jakarta: LP3ES.

Alisjahbana, S. (1977). The development of the cultural history of Indonesia: Values perspective [in bahasa Indonesia]. Jakarta: Idayu Press.

Anton Athoillah Hasyim, M. (2003, Juni 17). Sundanese community orientation, is Islamic Sundanesse or Sundanese Islamic? [in Bahasa Indonesia]. Pikiran Rakyat, pp. A4. 
Baum, R. J., \& Locke, E. (2004). The relationship entrepreneurial traits, skill, and motivation and subsequent venture growth. Journal of Applied Psychology, 89(4), 587-598. http://dx.doi.org/10.1037/0021-9010.89.4.587

Cable, D. M., \& Shane, S. (1997). A prisoner's dilemma approach to entrepreneur-venture capitalist relationships. Academy of Management Review, 22(1), 142-176.

Castles, L. (1988). Behavior of religion, politics and economics in Java: Tobacco industry at Kudus [in Bahasa Indonesia]. Jakarta: LP3ES.

Diaz, F., \& Rodriguez, A. (2003). Locus of control, nAch and values of community entrepreneur. Social Behavior and Personality, 31(8), 739-748. http://dx.doi.org/10.2224/sbp.2003.31.8.739

Edi, S. E. (2005). Sundanese culture, a historical approach [in Bahasa Indonesia]. Jakarta: Pustaka Jaya.

Elis Suryani Ns. (2007). Sundanese people's view about the relationship between humans and their communities [in Bahasa Indonesia]. Retrieved from http://resources_unpad.ac.id

Flora, J. L. (1998). Social capital and communities of place. Rural Sociology, 63, 481-506. http://dx.doi.org/10.1111/j.1549-0831.1998.tb00689.x

Foley, D. (2003). An examination of Indigenous Australian entrepreneurs. Journal of Developmental Entrepreneurship, 8(2), 133-151.

Gladney, D. C. (1999). Being rich is not so noble: Contrasting perspectives of prosperity among Muslims and Han in China [in Bahasa Indonesia]. In R. W. Hefner (Ed.) Culture market: Community and morality in the New Asian Capitalism (pp. 12-23) Jakarta: LP3ES.

Hamilton, G. H. (1999). Cultural and economic organization of the market at Taiwan [in Bahasa Indonesia]. In R. W. Hefner (Ed.) Culture Market: Community and morality in the New Asian capitalism (pp.84-100). Jakarta: LP3ES.

Hofstede, G. (1980). Culture's consequence: International difference in work related values. London: Sage.

Jennings, D. F. (1994). Multiple perspectives of entrepreneurship: Text, reading, and cases. Cincinnati: South-Western Publishing Co.

Kao, H. S. R., \& Ng, S. H. (1988). Reorganizing values for development. In D. Sinha \& H. S. R. Kao (Eds.) Introduction: Values development congruence (pp. 275-284). New Delhi: Sage Publication.

Kartodirdjo, S. (1993). Cultural development in historical perspective [in Bahasa Indonesia]. Yogyakarta: Gajah Mada University Press.

Kit Sum Lam, S. (1999). Portraits of successful entrepreneurs and high-flyers, a psychological perspective. Aldershot: Ashgate.

Koentjoroningrat. (1983). Culture, mentality and development [in Bahasa Indonesia]. Jakarta : Gramedia. Krauss, S. I., Fress, M., Friederich, C., \& Unger J. M. (2005). Entrepreneurial orientation: A psychological model of success among Southern African small business owner. European Journal of Work and Organizational Psychology, 14(3), 315-334.

Kroeber, A. L. (1948). Anthropology. New York: Harcourt Brace and Co.

Liang. T. W. (2004). Entrepreneurship development: The necessary condition. In D. Hew \& W. N. Loi (Eds.). Entrepreneurship in SMEs in Southeast Asia. (pp. 7-23). Singapore: ISEAS.

Moha Asri Hj. Abdullah. (1997). Small industry in Malaysia: Development and future [in Malay]. Kuala Lumpur: Dewan Bahasa dan Pustaka.

Mohamad Sobary. (1995). Piety and economic behavior [in bahasa Indonesia]. Yogyakarta: Yayasan Bentang Budaya.

Mohapatra, S., Rozelle, S., \& Goodhue R. (2007). The rise of self-employment in rural China: Development or distress? World Development, 35(1), 163-181. http://dx.doi.org/10.1016/j.worlddev.2006.09.007

Mustaffa Omar. (2002). Configuration values and assessment of the Malays: Handle future challenge [in Malay]. In Abdullah Hassan (Ed.), Proceedings of the 2nd International Conference of Malay Studies. Kuala Lumpur: Dewan Bahasa dan Pustaka.

Mustaffa Omar. (2008). Value orientation and evaluation of indigenous communities in Cameron Highlands: A comparative analysis. Paper presented on the first conference of education as generator for housing Orang Asli Community [in Malay], Darus Iman Malaysia, Campus. 
Raharjana. (2003). Business tactics of santri [in bahasa Indonesia]. In Ahimsa Putra (ed.). Economic, moral, Rational and Politics in Small Industry in Java (pp.123-186) Yogyakarta: Kepel.

Ravrisond Baswir. (2000). Underdevelopment of small businesses and increased local autonomy [in Bahasa Indonesia]. Jurnal Analisis Sosial, 5(1), 47-56.

Redding, S. G. (1980). Cognition as an aspect of culture and its relation to process: An exploratory view of the Chinese case. Journal of Management Studies, 17(2), 127-148.

http://dx.doi.org/10.1111/j.1467-6486.1980.tb00080.x

Rokeach, M. (1973). The nature of human values. New York: Free Press.

Sadoko. (2004). Policy for economic people [in bahasa Indonesia]. Jurnal Analisis Sosial, 9(2), 93-115.

Smith, A. S., \& Davis F.S. (2004). Psychologist as detective, an introduction to conducting research in psychology (3rd ed.). New Jersey: Pearson Prentice Hall.

Worldbank. (2001). World development report. Washington DC: World Bank.

Zahra, S. A. (1999). The changing rules of global competitiveness in the $21^{\text {st }}$ century. Academy Management Executive, 13(1), 36-42. 
Hidayat, D. R. 